\title{
The Communication Strategies for Moderate Islamic Da'wah in Countering Radicalism in Gorontalo City, Indonesia
}

\author{
ERWIN JUSUF THAIB \\ Institut Agama Islam Negeri (IAIN) Sultan Amai Gorontalo, Indonesia
}

\begin{abstract}
This study focuses on moderate Islamic da'wah communication strategies in counteracting radicalism in Gorontalo City. In Indonesia, radicalism has continuously occurred in the form of suicide bombings leading to lots of life, properties and numerous environmental hazards. Using da'wah as a communication strategy to counteract this violent act by spreading Islamic understanding may affect the community's attitude. The location was chosen because, besides being the centre for preaching activities, it also has greater social and religious dynamics than the other cities in the province. Meanwhile, the problems in this research are focused on two aspects, which are the content and methods of the moderate Islamic da'wah communication applied by the preachers to counteract radicalism in Gorontalo City. Data were purposively collected from eight preachers through interviews, observations, and documents. The result showed that these strategies were focused on the content of da'wah communication, especially the message and use of the verses. Also, several strategies were utilized by the preachers, which included shaping the community's religious understanding and reaffirming the position of Muslims as ummatan wasathan. Other strategies were seeking moderate religious references, examining the noble values of Gorontalo culture and customs, and encouraging people to respect and accept diversity.
\end{abstract}

Keywords: Communication strategy, da'wah, Gorontalo, moderate Islam, radicalism.

\section{INTRODUCTION}

The use of da'wah is unavoidable in the Islamic community. According to Max Muller (in Arnold, 1981), Islamic history has shown that it is a religious ideology that tends to exist in all parts of the earth. Syafriwaldi (2017) stated that da'wah adherents are expected to preach Islam all over the world. Due to this phenomenon, it has existed since the inception of Islam from the days of the Prophet Muhammad (MPBUH). Presently, da'wah is defined as a vehicle that has been used by many in building the Islamic societies. It serves as a means of education for the people, eradicating poverty, improving the quality of life in the community, and also abolishing various social problems (Basit, 2016).

Radicalism is one of the social problems that is currently being encountered by modern society (Maskur, 2018). It is understood to be an action against the state, which uses Islamism as an ideological foothold, and is very hard to demand change (Panjaitan, 2020; Zuhdi, 2019). The followers of this belief are rigid and uncompromising in their efforts to realize ... agendas (Naim \& Muhajir, 2020). It is the tendency to use violence to achieve both political and social goals (Septian, 2010). These persons are also connected with global terrorist networks such as the Afghan Mujahideen, al-Qaeda, and ISIS (Mubarok \& Fauzi, 2018). Purwantini and Bramantio (2018) stated that radicalism starts with perceptions which lead to attitudes and end in radical actions such as terrorism due to wrong understanding of Islam. Occasionally the seeds of radicalism are developed from Islamic education environment such as pesantren (Farida, 2015). Indonesia has experienced several terrorist attacks, including incessant suicide bombings which have led to the deaths of many people 
(Sumitro, 2015). Due to these adverse effects, the de-radicalization movement was initiated, in a bid to prohibit this unethical activity (Arifin, 2016; Hilmy, 2013; Golose, 2009; Khamdan, 2015; Koehler, 2017). However, the de-radicalization movement was not only initiated by the government, but the community also acknowledged it through various religious and social organizations. Da'wah is believed to be a powerful media for curbing radicalism because it is often initiated due to religious issues.

Religious moderation is another way to counter radicalism. It is aimed at fostering religious tolerance and avoiding radical attitudes. Religious moderation, particularly in Islam, is an attitude that always tries to take a middle way (Saidurrahman, 2019). This concept is perceived as an ideal religious attitude accepted by all and is disseminated through various media. Da'wah is also an effective medium of communication, a massive religious activity in any Islamic community, including the city of Gorontalo.

This research was carried out in Gorontalo City because, in addition to being the centre for preaching activities, it also has greater social and religious dynamics than the other cities in the province. Therefore, the phenomenon of encountering problems of radicalism in society is more evident in the city. Gorontalo City is an area majorly inhabited by Muslims, and these people accounted for $97.12 \%$ of the population, according to the city's Central Statistics Bureau (2018). Consequently, one of the biggest religious activities in the city is da'wah, which can be used as a vehicle to shape society in a better direction and prevent them from bad deeds, including radicalism.

According to Umar (2010), the eradication of radicalism in society is usually carried out by a violent approach, so a softer tactic will be formulated in this study by using a moderate strategy. Based on the background above, the focus of this research is to examine the communication strategies of moderate Islamic da'wah in counteracting radicalism in Gorontalo City. Two major problems, which are the content and methods of these moderate strategies, are analyzed in this study.

\section{LITERATURE REVIEW}

$D a^{\prime} w a h$

Da'wah is a means of communicating Islamic teaching for followers to embrace peace and safety. However, in order to accomplish this, the teachings of Islam need to be properly understood. Therefore, the right Islamic communication method is needed to as an effort to build a relationship with oneself, the Creator and others in order to achieve peace, hospitality and salvation by submitting to the commands of Allah and the Messengers (Hefni, 2015).

Da'wah is a form of Islamic communication that is in accordance with the opinion of Littlejohn (2001) which stated that dialogues between humans are identified with the number of participants. Therefore, the activities of the perpetrators of this act are also referred to as "da'wah communication". Suhaimi (2007) stated that the activities of the Prophets and Muslims in carrying out the command of Allah by inviting people to the teachings of Islam is known as da'wah. It is an Islamic broadcasting mechanism that uses its methodologies and media-oriented towards the world and beyond at an appropriate place and time (Abdullah et al., 2014). Bakti (2018), defined it as the science of Islamic communication, which examines the message of the sender, the understanding of its receiver, the media used and the effects that arise from this process. The process involved in Islamic communication tends to change or develop a society following morals, ethics, and character. 
Arifin (1988) formulated the stages of an effective communication process using the Lasswell Formula as follows: 1) the sender, 2) content of the message, 3) through what channel, 4) the receiver, and 5) the effect. This formula, according to Thaib (2014), is used to illustrate the fact that da'wah is one of the models of communication. The was further described below

Firstly, the sender is the subject of da'wah, i.e. preacher. In this case, the preacher acts as a communicator or source of information and teaches the various verses of the Qur'an or Hadith of the Holy Prophet. Every Muslim need to participate in the act of preaching according to their respective abilities, therefore, an ideal preacher is an excellent communicator that tends to deliver religious messages to Muslims.

Secondly, the content of the message means the teachings of Islam. This stage involves the contents of the intended communication process. According to the da'wah perspective, the message relates to the material that is carried and conveyed in its activities. Shihab (1997), reported that the materials proposed by the Qur'an and the Hadith revolves around three things, namely the issue of aqeedah, morals, and law.

Thirdly, through what channels, this means all the media used in da'wah. Channels in this context are the media used to convey messages. Da'wah, which is one of the communication models, also requires a channel for the delivery of its messages. In this era of sophisticated information technology, its channels have increased due to the presence of electronic media such as radio, television, internet, telephone. Siagian (2016) stated that television is among the most effective media used.

Fourthly, the receiver is the target or object of the preaching. In this section, the communication is conveyed to the receivers. They are also referred to as the communicants and partners to the communicator. This is also applicable in the da'wah activities. In this process, the objects are referred to as the communists.

Fifthly, the effect means studying the implications of da'wah. The effects of a communication activity are the changes that occurred after the process. Additionally, da'wah activities are expected to have a positive effect on the understanding, appreciation and practice of the teachings of Islam. It is a step forward towards creating a society that is in accordance with its objective of achieving happy and prosperous humanity in the world and beyond.

The above description proves that all the stages of an ideal communication process are involved in the implementation of the da'wah activities, which is an integral part of the transmitted information procedures (Kuswandi, 1996). Da'wah communicates the messages of Islam to the public to be acknowledged and obeyed, thereby creating peace.

\section{Moderate Islam as Middle Way}

Islam is related to moderation values (Prasojo, Elmansyah \& Masri, 2019), and Ni'am (2015) have stated that an idea that recently emerged in response to the Islamic situation which is often connoted as a terrorist religion and full of violence. The term moderate means to avoid extreme actions (Umar, 2016; Rusli, 2009). Moderate Islam is often interpreted as a religious practice that is neither extreme nor radical. According to John L. Esposito's view, the terms "moderate" and "moderatism" are conceptual nomenclature that is difficult to define. This term is contested by religious groups or scientists, on the fact that it is interpreted differently, depending on individuals and in the context that it is used. This difficulty is due to the fact that the treasures of Classical Islamic thought do not recognize the term "moderatism". Its 
usage and understanding usually refer to its equivalent in a number of Arabic words such as al-tawassuț or al-wasaț (moderation), al-qisț (justice), al-tawāzun (balance), al-i'tidāl (harmony) (Suharto, 2017).

According to Muhammad Ali, moderate Islam in Indonesia refers to the Islamic community that emphasizes on normal behaviour (tawassuț), implements tolerant religious teachings, avoidance of violence and promotes dialogue. They are the mainstream of Islam in the country, despite the fact that their strategic movements to moderate religion and politics are still considered limited. Ideas such as "indigenous Islam" (Rahmat, 2003), "rational Islam" (Nasution, 2019), "Progressive Islam" (Bustamam \& Ahmad, 2011), "transformative Islam" (Ali, 2017), "Liberal Islam" (Khan, 2003), "Inclusive Islam" (Shihab, 1997), "tolerant Islam" (Friedmann, 2003), and "plural Islam"(Hussain, 2009), which emerged since the 1970s are categorized as moderate Islam. This same category is also pinned on re-actualization, nationalization, deserialization of Islamic culture or contextual ijtihad (Suharto, 2017).

In contrast to Muhammad Ali's emphasis on the substance of moderate Islamic character, Ahmad Najib Burhani interpreted it in accordance to the meaning of the language, which is the "mid-position between liberalism and Islamism". People or organizations that are in the middle of liberalism and Islamism are perceived as moderate. Therefore, Burhani's view on moderate Islam is neither liberal nor Islamist (Suharto, 2017). It is a perception or view that always tries to take the middle position of two opposing or excessive attitudes, in order that one of the two notions referred to does not dominate one's mind and character (Amin, 2014).

Burhani's view above confirms that Muslims tend to take the mid-position (ummatan wasathan) in all matters, including the religious and social affairs of the world. Wasathiyah is the characteristics of Islam that is not shared by other religions. Moderate Islam entails tolerant Islamic propaganda, against all forms of liberal and radical thought. Nur and Mukhlis (2015) defined Liberal as the understanding of Islam with lust standards and pure logic that tends to seek unscientific justification.

According to the numerous views on moderate Islam, the Qur'an refers to its essence or substance as rahmmah li al-ālamin (Qur'an, 21:107). In accordance with this interpretation, moderate Islam in Indonesia is defined as a practice that is not extreme or radical and does not encourage violence or encounter hard lines during its implementation. Liberal Islamic or Islamist groups that do not toll the path of rahmah are not categorized as moderate Islam. Several features characterize moderate Islam, namely acting reasonably (tawassuț) during the implementation of religious teachings, tolerancing differences in opinions, avoiding violence, prioritizing dialogues, accommodating modern concepts that are substantially beneficial, rational thinking, interpreting text contextually, and using ijtihad in translating what is not contained in the al-Qur'an or Sunnah. Therefore, in accordance with the above characteristics, moderate Islamists are tolerant, harmonious and show a cooperative attitude towards other religious groups. The rahmah character is used in modern Indonesian Islamic teachings, which is more theological in meaning, than the politics that is often discouraged by the United States (Suharto, 2017).

The above review shows that the idea of moderate Islam is similar to the concept of the middle way, which simply means a religious attitude that does not tend towards extremity and radicality. It is, therefore, the middle way that embodies the face of Islam as a rahmatan lil-'alamin. 
The Da'wah of Moderate Islam and Its Contribution to Prevent Radicalism

Moderate Islam, in accordance with the middle way concept, is perceived as the solution to various world problems, particularly in the religious sector. This concept encourages people not to succumb to extreme and radical attitudes because they are not the ideal values of religion. It is also widely disseminated in the Islamic community, primarily through the propagation of da'wah.

The spread of the concept of moderate Islam in Indonesian is actually not new. According to Miftahuddin (2010), historically, the spread of moderate Islamic ideas in Indonesia was pioneered by Walisongo. This means that Islam is capable of being contextualized, without losing the principles and essence of its teachings. This concept became known as the "indigenization of Islam". The idea is intended to dilute the pattern and character of Islam as a normative religious practice into something that is contextual. The "indigenization of Islam", depicts that the essence of Islam as normative teaching that originated from God is to accommodate the human culture without losing their respective identities. To be more concrete, contextually Islam is understood as teachings that are related to era and location. Changes in time and regional differences are the keys for interpreting the ijtihad. Therefore, Islam tends to be continuously renewed and is dynamic in responding to changing times. In addition, it is able to engage in flexible dialogues with different communities all over the world. It is this ability to adapt in every era and place (shaalih li kulli zamaan wa makaan).

This concept was formed by the struggle of Indonesia's age-long Islamic history and had been revolving since after the Walisongo era. Muhammadiyah and NU are two Islamic organizations that promote the various forms of moderation, through the educational institutions they manage and the socio-political-religious activities they are involved. Therefore, these two organizations are referred to as civil society institutions that are important for the country's moderation process. Furthermore, they play an active role in maintaining and strengthening networks that support Islamic moderation, such as institutions, thereby projecting Indonesia as the pilot of tolerance in the outside world. It is also pronounced that $\mathrm{NU}$ is the largest Islamic organization in the country, and it has played a significant role in carrying out tolerant and peaceful ideas (Miftahuddin, 2010). The affirmation of the moderate position of $\mathrm{NU}$ and Muhammadiyah is one of the most important starting points in Indonesia's socio-political life (Puadi, 2014).

Muhammadiyah's moderation attitude was actually built since its inception by the founder of the organization, K. H. Ahmad Dahlan. It was discovered, that one of the most important lessons learnt from Ahmad Dahlan's leadership was a strong commitment to moderate attitude and religious tolerance. During his leadership, creative and harmonious cooperation was observed among different groups of people. In fact, with fellow Christian colleagues, they were able to inspire respect and admiration. The most interesting example of K.H Ahmad Dahlan is the close friendship with numerous Christian religious leaders. Despite the fact that K.H Ahmad Dahlan was known to be tolerant of Christian missionaries, it was ensured that Islamic principles were not compromised. Ahmad Dahlan is a true practitioner of interreligious dialogue, in the sense that Ahmad listens to what is said and pays attention to what is implied by spoken words (Miftahuddin, 2010).

According to Miftahuddin's (2010), NU's moderation attitude is basically not separated from Ahlusunnah waljama'ah (Aswaja) creed, which is classified as moderate. This attitude is widely taught in various pesantren, and it leads to an authentic character. Since its 
inception, the pesantren has always displayed a tolerant and peaceful reputation (Farida, 2015). However, moderate character (tawassuth) is the most prominent characteristic of Ahlussunah waljama'ah, asides from i'tidaal (being fair), tawaazun (being balanced), and tasaamuh (being tolerant), in order to reject all forms of radical actions and thoughts (tatharruf) that tends to give birth to deviations in Islamic teachings. According to the religious concept, a balance (middle way) is developed between the use of revelation (naqliyah) and ratio ('aqliyah) in order to possibly accommodate changes in the society as long as it does not oppose dogmatic doctrines. In accordance with the consequences of moderate attitudes, Ahlussunah waljama'ah also exhibits tolerant attitudes towards tradition compared to other Islamic groups, because for Ahlussunah maintaining tradition has an important significance in religious life due to the fact that it is not abolished entirely, neither is it completely acceptable, however, it seeks to be gradually Islamized.

Moderate Islam that encourages Muslims to be fair, tolerant and abstain from extreme attitudes causes the exposed ones to publicize the ideal attitude of letting peace reign. Tolerance and avoidance of extreme attitudes are values that are required in building a harmonious and peaceful world. The ideal values offered by this concept contribute significantly to the generation of peace in an increasingly dynamic world full of constant threats.

\section{METHODOLOGY}

This study employed a qualitative approach. A qualitative method is used to analyze the effect of communication strategies employed by the moderate Islamic da'wah in countering radicalism. Data was collected by interviews, observations and document study methods (Sugiyono, 2015). The research informants were the preachers of the city, and they were purposely selected. Interviews were conducted on 8 of the preachers using the snowball system. They were selected because they had a better understanding of the issues being examined. Observations were carried out in a participatory manner in which the researchers and the informants got involved in da'wah activities. Document studies are conducted on records that are relevant to the research theme. According to Moleong (2013), qualitative analysis is an effort made by working with data. These efforts include organizing and sorting data into manageable units, synthesizing it, seeking and finding patterns, discovering important and learned information, and deciding what can be told to others. Therefore, the data in this study was descriptively analyzed by methods, which evaluate, describe, and summarize various conditions. Situations from various data were collected as documents, interviews, or observations regarding the study problems that occurred in the organizing field. Meanwhile, the data analysis stage focused in-depth on the content and moderate strategies of da'wah communication in counteracting radicalism in Gorontalo City. Data were analyzed by evaluating and reviewing all information obtained from the informants during the collection, reduction, display, withdrawal or verification process until conclusions were made.

Table 1: Informants

\begin{tabular}{cc}
\hline Name & Position \\
\hline K. H. Abd. Rasyid Kamaru & Preacher \\
K. H. Abd. Muin Mooduto & Preacher \\
Ahmad Mulane & Preacher \\
Syarifuddin Mahmud & Preacher \\
Sukarno Thaib & Preacher \\
\hline
\end{tabular}




\begin{tabular}{cc}
\hline Surahmin Alinti & Preacher \\
Moh. Iqbal Pakaya & Preacher \\
Haris Hako & Preacher \\
\hline
\end{tabular}

\section{RESULT AND DISCUSSION}

The results from this study showed two main aspects, namely the content and the communication strategy of moderate Islamic da'wah used by the preachers.

\section{The Communication Content of Moderate Islamic Da'wah}

Moderate Islam is discovered in the Al-Qur'an and Hadith as well as in the behaviour of prophets and friends. In the Qur'an, for example, the concept of Islamic moderation is found in a number of verses and provides flexibility in its teachings with regards to Islamic laws. Legal flexibility in the Qur'an means changing a law in accordance with its real context and conditions of humanity. Al-Qur'an recognizes both the normal and abnormal Islamic laws termed emergency by experts. The recognition of an emergency is a solid foundation for the birth of Islamic moderation because its concept is a translation of Islam's partiality towards humanity.

However, in the teachings by the prophets, Islamic moderation are reflected in several legal decisions made by different friends concerning a particular circumstance. The Prophet always considered aspects of human history in the implementation of the teachings of the Qur'an, which were translated for the benefit of humanity and not to inflict pains. This context reflects the teachings of convenience in moderate Islam. This practice does not distinguish mankind according to their ethnicity, religion, and race. Every individual is the same before the law. All have the right to receive fair treatment without being discriminated. This condition also reflects the attitude of openness, better known as inclusivism (the opposite of exclusivism) of Islamic teachings. An inclusive attitude means accepting and realizing the presence of other religions in the community/state, and at the same instance, ensuring that they do not lose their identity.

Moderate Islam is a concept of moderation that encourages the principle of justice and balance in every step and speech in the pluralities of the society in order to create peace and tolerance without any acts of anarchism and exclusivism. The word moderate is also, often interpreted as a method of thinking, interacting and behaving in a tawaazun (balanced) manner when addressing two conditions, in order that the people exhibit certain attitudes in accordance with the Islamic principles and community traditions, namely balanced in creed, worship, and morals (Pettalongi, 2019).

To instil the concept of moderate Islam in the community, a certain approach that is likely to be used is da'wah. This is because it is one of the activities in the Islamic community that occurs continuously, therefore, making it suitable for instilling moderate Islamic values in all the communities, including the city of Gorontalo. The implementation of this concept based on the communication content of moderate Islamic da'wah consists of two main aspects namely.

\section{The Message of $D a^{\prime}$ wah}

This message is the main factor of the communication process and is a major element used to counter radicalism in society. The preachers used it as part of the communication strategy to support this concept. The Gorontalo city was among others that raised the main historical aspects carried out by the Prophet Muhammad. The Holy Prophet showed a tendency 
towards religious moderation by treating people of different faiths, prisoners of war, and also evil people moderately. Presently, these examples inspire the inhabitants of the city to carry out this concept.

In this context, the message promotes the concept of moderate Islam and plays a significant role in shaping religious diversity. It also encourages teachings of respect for humanity, differences in diversity, religious attitudes that emphasize justice and balance, worldly and ukhrowi aspects, as well as other substances that prevent hazardous attitudes.

The Da'wah message chosen by the preachers tends to prioritize the concept of moderate Islam and also plays a role in shaping the community to become a religious society that sustains its customs and the traditions of their ancestors that have strong ties to Islamic values. Although presently the invasion of global influence has affected the social order of the city, however strong ties exist between the people, religion and culture which is influenced by the factors of moderate Islamic teachings carried out by the preachers.

\section{The Dalil (verses)}

Different perceptions of religious verses sometimes trigger certain attitudes, such as moderate or radical. In the case of religious radicalism, particularly in Indonesia, it was observed by the emergence of certain groups that tends to force Islam to be realized even though it involves the use of violence. This is in accordance with their understanding of the different verses. Another aspect which is quite prominent is the choice of verses that are referenced during preaching. To be submissive to da'wah message, an argument is considered imperfect whenever it is not supported by the verses of the Qur'an or the hadith of the Prophet Muhammad. Conversely, it needs to be built on the foundation of the sources of Islamic teachings such as the Qur'an and the hadith of the Prophet Muhammad. The reason is that preaching is from the two main sources.

It is admitted that the verses of the Qur'an and the hadith of the Prophet Muhammad were emerge in a specific context. Generally, some verses and hadiths have the tendency to be difficult and decisive, while some tend to be smooth and indecisive. In da'wah, there are no restrictions on the use of the verses. All verses as long as it is valid are used. However, sometimes problems arise such as wars, jihad, as well as the issues between Muslims and the infidels.

The preachers in carrying out the concept of moderate Islam through da'wah always chose a defensive understanding approach in responding to the diverse conditions of society in terms of beliefs, religion, local customary law and cultural practices and various other aspects. All of this was carried out in order to keep the community from exhibiting extremism due to provocative da'wah messages. Phenomena such as this are actually rare because da'wah in this city is still an ongoing process. This is supported by the attitude of the preachers, by showing moderate tendencies, particularly in interpreting the verses in da'wah in order to avoid the tendencies of radicalism.

The two aspects above describe how the implementation of the concept of Islamic moderate in da' wah is carried out by the preachers. The implementation of these concepts is emphasized on the message aspects and the verses used in the context of encouraging the people to uphold the values of justice, balance, tolerance and civilization. 


\section{Communication Strategies of Islamic Moderate Da'wah in Countering Radicalism}

Radicalism is basically an understanding of certain individuals to threaten the lives of people wherever they are. The knowledge that drives the person to think, and act radically in its essence, is a threat to humanity. There have been many victims in Indonesia and in other countries due to various actions triggered by radicalism, religious understanding, political ideology, and other problems in the society (Zainiyati, 2016).

Da'wah is a powerful tool that is used to fight radicalism in society, particularly preachings that promotes the concept of moderate Islam. It employs the appropriate communication strategy. This strategy is a combination of preaching and management planning employed to achieve a specific goal (Mahmudin \& Aisyah, 2019). The conception of moderate Islam requires a strategy that encourages people not to be extreme in religious practices and need to be perceived as a party that maintains balance and upholds justice for all humans. The concept of moderate Islam is an ideal idea in fighting radicalism in society.

The communication strategy also determines the success or failure of the preaching. It involves the strategy of selecting missionary messages that need to be developed in order to achieve the objectives of the preaching. Present-day preachers need to develop communication skills with diverse objects and media utilization strategies (Weng (2018). Some of the communication strategies adopted by the preachers are described as follows.

\section{Shaping Community Religious Understanding}

Understanding radicalism tends to start from an exclusive mindset, and it is also characterized by what is understood as absolute truth. Therefore, different perspectives tend to lead to radicalism automatically. Such phenomena are actually very common in society, particularly when it has to do with religious matters. However, when thoroughly viewed, it tends to have varying perspectives because they are influenced by various factors such as schools, religious organizations levels of education, and the environment (Munawati, 2019).

In order to counteract the birth of radicalism, religious understanding in accordance with the concept of moderate Islam needs to be part of the solutions to this problem. Moderate religious understanding prevents individuals from exhibiting extremism and intolerance. Moderate Islam encourages moderation in religion, and the acceptance of differences is perceived as a natural thing.

Da'wah is a vehicle that is capable of developing moderation and the tendency for widespread radical understanding in society. The continuous existence of da'wah tends to be able to influence and monitor religious understanding in the city. It also avoids the perception of radicalism. The preachers with their strong perception of the concept tend to be able to teach the people ideal religious practices in accordance with moderate Islam.

\section{Reaffirming The Position of Muslims as Ummatan Wasathan}

Moderate Islam is basically a concept that is derived from the Muslim terminology 'ummatan wasathan' as set out in the Qur'an. Al-Ashfahaniy, defines wasathan as sawal', the middle between two boundaries. However, Ibn Asyur stated that the word wasath has two meanings firstly, it was defined as something in the middle. Secondly, it was defined as Islamic values built on a straight and middle mindset and are not exaggerated in certain respects (Nur \& Mukhlis, 2015). 
Muslims in the city have long lived in moderate religious situations shielded by the two socio-religious organizations namely NU and Muhammadiyah. Therefore, the inhabitants have never been plunged into extremism. However, present-day religious phenomenon tends to be troubling, particularly with the spread of extremism both in the real world and in cyberspace. Therefore, it is feared to threaten the religious moderation in the city of Gorontalo. This is the reason, da'wah was implemented by the preachers in the city to fortify the Muslims from the threats of radicalism and strengthen their position as ummatan wasathan.

\section{Look for Moderate Religious References}

Generally, some religious individuals tend to refer to certain figures due to their guidance as to the path of truth. This practice is actually common in most Indonesian society. For example, the religious literature contains numerous kiai referred to as central figures in diverse positions such as references and role models of religious behaviour. In the tradition of Sufism also known as the murshid or musyrif, they are referred to as spiritual teachers or role models (Akmansyah, 2015; Mustofa, 2009).

The people are encouraged to refer to the appropriate religious references in order to prevent the Muslims from radical ideas that threaten the peace and harmony in the city. Da'wah, in accordance with moderate Islamic concepts offers an idea of the ideal religious characteristics and reference figures. The preachers are ideal religious role models because they always encourage the Muslims to go on a straight and balanced religious path and to avoid extreme attitudes which are contrary to Islamic religious principles.

\section{Examining The Noble Values of Gorontalo Culture and Customs}

Gorontalo City is an area inhabited by a population that is predominantly Muslim. The Islamic religion has been the official belief of the people since its inception. It has also become the reference of all activities including those related to rituals or Shari'a, as well as those related to the customs and habits of the people. It is therefore understood that Gorontalo is known by its philosophy which is "Adati hula hula'a to sara'a, sara'a hula hula'a to Kuru'ani" interpreted as "a custom in accordance with syara' (syari'at/Islamic law) and syara' in relation to Kitabullah (Al-Qur'an). This philosophy later became the frame of the Gorontalo Islamic tradition (Hasanuddin \& Amin, 2012).

Moderate Islamic da'wah is used to study the noble values of the people because practically the inhabitants have accepted this concept as a whole. In the entire history of the inhabitants, protests concerning the issue of dominance of local customary law over religion or in other practices have never been recorded, until lately with the outbreak of transnational religious understanding in many communities in the city. The preachers continued to explore the noble principles of the people as a manifestation of the religious values in society.

\section{Encourage People to Respect and Accept Diversity}

Demographically the population of the Gorontalo City is inhabited by a majority of Muslims. Statistics show that Islam is practised by approximately $97.12 \%$ of the population while the remaining $2.88 \%$ are Christians, Catholics, Hindus and Buddhists (BPS Kota Gorontalo City Central Statistics Bureau, 2018). According to this data, Islam is the dominant religion in the entire city. However, on the other hand, there are also followers of other religions in the community. 
In addition to the diverse religions, there are also other variations, such as the ethnic aspects. There are other tribes such as the Minahasa, Sangir, Arabic, Bugis, Javanese, Batak, Padang, etc. however, the Gorontalo tribes are the majority. It is a pluralist city due to its ethnic diversity. In addition to these diversities, there are also other forms in society.

The above analysis shows that the moderate Islamic da'wah communication strategy has played a significant role in counteracting radicalism in the city. This research has also provided theoretical contributions to the scientific development of Islamic communication. According to Hefni (2015), Islamic communication is built on principles that have the spirits of peace, hospitality, and safety and tends to create these values. Consequently, this can be fulfilled with a moderate da'wah approach that can communicate Islam as a peaceful, friendly, and safe religion.

\section{CONCLUSION}

This research was conducted to obtain a moderate Islamic da'wah communication strategy to prevent radicalism in Gorontalo City. The findings of this study focused on two aspects, which are the moderate Islamic da'wah communication content and strategies used by preachers in the city. Meanwhile, the content aspect was divided into two parts, the message of the da'wah and the verses used. The message employed in supporting the concept of moderate Islam preached in the society was by raising the historical aspects of the Prophet Muhammad that showed tendencies towards religious moderation. In terms of the verses used, the preachers put forward the approach of defensive interpretation and aspects of tolerance and fairness of humanity. Therefore, the moderate Islamic da'wah communication strategy used by the preachers in counteracting radicalism involves shaping community religious understanding, reaffirming the position of Muslims as ummatan wasathan, and seeking moderate religious references. It also entails examining the noble values of Gorontalo culture and customs, as well as encouraging people to respect and accept diversity. Consequently, this moderate Islamic da'wah communication strategy can protect Gorontalo City from the current threats of radicalism.

\section{BIODATA}

Erwin Jusuf Thaib is a Senior Lecturer at the Department of Islamic Communication, Faculty of Ushuluddin and Da'wah, Institut Agama Islam Negeri (IAIN) Sultan Amai Gorontalo, Indonesia. His research interests are about da'wah and communication, especially da'wah and its relation to various media, communication studies, and religious studies. Email: erwinjthaib@iaingorontalo.ac.id 


\section{REFERENCES}

Abdullah, A. M., Tibek, S. R., Dakir, J., \& Md Sham, F. (2014). The message of dakwah in television drama on Egyption TV channel 1. International Journal of West Asian Studies, 6(1), 13-24.

Akmansyah, M. (2015). Eksistensi guru (mursyid) dalam perspektif pendidikan spiritual perspektif Abu Hamid Al-Ghazali (1058 M-1111M). At-Tadzkiyyat: Jurnal Pendidikan Islam, 6, 307-323.

Ali, M. (2017) Arus pendidikan Islam transformatif di Indonesia: Sebuah penjajagan awal, Jurnal SUHUF, 29(1), 1-14.

Amin, A. R. M. (2014). Prinsip dan fenomena moderasi Islam dalam tradisi hukum Islam. Jurnal Al-Qalam, 20(2), 23-32.

Aminuddin. (2016). Konsep dasar dakwah. Jurnal Al-Munzir, 9(1), 29-46.

Arifin, A. (1988). Ilmu komunikasi, sebuah pengantar ringkas. Jakarta: Rajawali Press.

Arifin, S. (2016). Islamic religious education and radicalism in Indonesia: Strategi of deradicalization through strengthtening the living values education. Indonesian Journal of Islam and Muslim Societies, 6(1), 93-126.

Arnold, T. W. (1981). Sejarah da'wah Islam (The spread of Islam in the world: A history of peaceful preaching, terj. Nawawi Rambe). Jakarta: Widjaya.

Bakti, A. F. (2018). Media and religion: Rodja TV's involvement in the civil society discourse for community development. Jurnal Komunikasi: Malaysian Journal of Communication, 34(3), 226-244.

Basit, A. (2016). The ideological fragmentation of Indonesian Muslim students and da'wa movements in the post reformed era. Indonesian Journal of Islam and Muslim Societies, 6(2), 185-208.

Biro Pusat Statistik. (2019). Kota Gorontalo dalam angka 2018. Kota Gorontalo: Penulis.

Bustamam, \& Kamaruzzaman, A. (2011). Contemporary Islamic thought in Indonesia and Malay world: Islam liberal, Islam hadhari and Islam progresif. Journal of Indonesian Islam, 5(1), 91-129.

Farida, U. (2015). Radikalisme, moderatisme, dan liberalisme pesantren. Jurnal Edukasia, Jurnal Penelitian Pendidikan Islam, 10(1), 145-163.

Friedmann, Y. (2003). Tolerance and coercion in Islam, interfaith relation in the Muslim tradition. Cambridge: Cambridge Press.

Golose, P. R. (2009) Deradikalisasi terorisme, humanis, soul approach, dan menyentuh akar rumput. Indonesia: Yayasan Pengembangan Kajian Ilmu Kepolisian.

Hasanuddin, \& Amin, B. (2012). Gorontalo dalam dinamika sejarah masa colonial. Yogyakarta: Penerbit Ombak.

Hefni, H. (2015). Komunikasi Islam. Jakarta: Pranamedia Group.

Hilmy, M. (2013). The politics of retaliation: The backlash of radical Islamists and deradicalization Project in Indonesia, Al-Jami'ah, 51(1), 129-158.

Hussain, A. (2009). Islam in the plural. London: Institute of Ismaili Studies.

Khamdan, M. (2015). Rethinking deradikalisasi, konstruksi bina damai penanganan terorisme. Jurnal ADDIN, 9(1), 181-204.

Khan, M. (2003). Radical Islam, liberal Islam. Current History, 102(668), 417-421. https://doi.org/10.1525/curh.2003.102.668.417

Koehler, D. (2017). Understanding deradicalization, methods, tools, and programs for countering violent extremism. New York: Routledge. 
Kuswandi, W. (1996). Komunikasi massa, sebuah analisis media televisi. Jakarta: Rineka Cipta. Littlejohn, S. W. (2011). Teori komunikasi. Jakarta: Salemba Empat.

Mahmuddin, \& Aisyah BM, ST. (2019). Strategy communication and da'wah in reducing Uang Pana'i of marriage in Bulukumba. Jurnal Komunikasi: Malaysian Journal of Communication, 35(3), 92-107.

Maskur, M. A. (2018). Criminal policy against distribution of radicalism ideology of Islamic state of Iraq and Syria (ISIS) at higher education in Indonesia. International Journal of Business, Economics and Law, 15(4), 107-110.

Miftahuddin. (2010). Islam moderat konteks Indonesia dalam perspektif historis. Jurnal Mozaik, 5(1), 41-54.

Moleong, L. J. (2013). Metode penelitian kualitatif. Bandung: PT Remaja Rosdakarya.

Mubarok, Z., \& Fauzi, A. (2018). The rise of radicalism and terrorism in Indonesia and Malaysia. Review of Islam in Southeast Asia, 1, 29-43.

Munawati, S. (2019). Trend hijab dan pandangan keagamaan melalui pendidikan berbasis kearifan local. ALIM: Journal of Islamic Education, 1(2), 405-426.

Mustofa. (2009). Tinjauan budaya atas kultur tasawuf berbasis mursyid perempuan. Jurnal elHarakah, 11(2), 105-117.

Naim, N., \& Muhajir, A. (2020). Islamic radicalism and de-radicalization strategies: A contribution of Nurcholish Madjid. Jurnal IImiah Islam FUTURA, 20(2), 235-253.

Nasution, S. (2019). Islam rasional. Ijtimaiyah: Jurnal Pendidikan Ilmu Sosial dan Budaya, 3(1), 1-9.

Ni'am, S. (2015). Pesantren: The miniature the moderate Islam in Indonesia. Indonesian Journal of Islam and Muslim Societies, 5(1), 111-134.

Nur, A., \& Lubis, M. (2015). Konsep wasathiyah dalam Al-Qur'an. Jurnal An-Nur, 4(2), 205-225.

Panjaitan, S. (2020). Transformation of radicalism discourse into extremist violence: Analysis of news on the handling of radical movements in Indonesia. Jurnal Studi Sosial dan Politik, 4(1), 18-31.

Pettalongi, S. S. (2019). Kearifan lokal dalam bingkai Islam noderat: Sebuah konsep untuk implementasi pada IAIN Palu. DIm. Ahmala Arifin (pnyt.), Moderasi beragama dari Indonesia untuk dunia. Yogyakarta: LKiS.

Prasojo, Z. H., Elmansyah, \& Masri, M. S. (2019). Moderate Islam and the social construction of multi ethnic communities in the Hinterland of West Kalimantan. Indonesian Journal of Islam and Muslim Societies, 9(2), 217-239.

Puadi, H. (2014). Muslim moderat dalam konteks sosial politik di Indonesia. Jurnal Pusaka, Juli-Desember, 4-13.

Purwantini, B. (2018) The adventure of the radical Islamic group members of the free Aceh movement in Seumpama Matahari novel. Journal of Indonesian Islam, 12(2), 85-102.

Rahmat, M. I. (2003) Islam pribumi: Mendialogkan agama membaca realitas. Jakarta, Erlangga.

Rusli. (2009). Gagasan Khaled Abu Fadl tentang Islam moderat versus Islam puritan: Perspektif sosiologi pengetahuan. Jurnal Ilmu Ushuluddin, 8(1), 99-123.

Saidurrahman, T. G. S. (2019). Penguatan moderasi Islam di Indonesia dan peran PTKIN. DIm. A. Arifin (pnyt.), Moderasi beragama dari Indonesia untuk dunia. Yogyakarta: LKiS.

Septian, F. (2010). Pelaksanaan deradikalisasi Narapidana terorisme di Lembaga Pemasyarakatan Kelas I Cipinang. Jurnal Kriminologi Indonesia, 7(1), 108-133.

Shihab, A. (1997). Islam inklusif, menuju sikap terbuka dalam beragama. Bandung: Mizan. 
Shihab, HM Q. (1997). Membumikan Al-Qur'an. Bandung: Mizan.

Siagian, H. F., \& Fauziah Ahmad. (2016). The position of da'wah messages and ethics in Malaysian and Indonesian programs. Jurnal Komunikasi: Malaysian Journal of Communication, 32(2), 749-769.

Sugiyono. (2015). Memahami penelitian kualitatif. Bandung: Penerbit Alfabeta.

Suhaimi. (2007). Komunikasi dakwah Imam Hanbali. Dakwah: Jurnal Kajian Dakwah dan Komunikasi, 9(1), 85-96.

Suharto, T. (2017) Penguatan Islam moderat dalam Lembaga Pendidikan Islam di Indonesia, Jurnal Al-Tahrir, 17(1), 155-178.

Sumitro, W. (2015). Deconstruction of jihad radicalism in Islamic Law: A conceptual proposal to combat ISIS terorism in Indonesia. Global Journal Al-Thaqafah (GJAT), 5(2), 7-18.

Syafriwaldi. (2017). Dakwah dan masalah kontemporer. Jurnal Al-Fuad, 1(1), 44-53.

Thaib, E. J. (2014). Studi dakwah dan media dalam perspektif uses and gratification theory. Jurnal Farabi, 11(1), 1-23.

Umar, A. R. M. (2016). A genealogy of moderate islam: Govermentality and discourses of Islam in Indonesia's foreign policy. Studia Islamika, 23(3), 399-433.

Umar, A. R. M. (2010). Melacak akar radikalisme Islam di Indonesia. Jurnal IImu Sosial dan IImu Politik, 14(2), 169-186.

Weng, H. W. (2018). The art of dakwah: Social media, visual persuasion, and the Islamist propagation of Felix Siauw. Indonesia and The Malay World, 46(134), 61-79.

Zainiyati, H. S. (2016). Curriculum, Islamic understanding, and radical Islamic movement in Indonesia. Journal of Indonesian Islam, 10(2), 285-308.

Zuhdi, M. H. (2019). Potential Islamic radicalism and terrorism in the province of West Nusa Tenggara. Ahkam: Jurnal IImu Syariah, 19(1), 97-126. 